\title{
FORMATION OF ORGANIC MOLECULES BY FORMALDEHYDE REACTIONS IN ASTROPHYSICAL ICES AT VERY LOW TEMPERATURES
}

\author{
W. A. SCHUTTE, L. J. ALLAMANDOLA, and S. A. SANDFORD \\ Space Science Division, MS:245-6, NASAAmes Research Center, Moffett \\ Field, CA 94035, U.S.A.
}

\begin{abstract}
Warm-up of astrophysical ice analogues containing formaldehyde produced organic residues in large abundances. It is argued that formaldehyde reactions at very low temperatures could be an important source of interstellar and cometary organic molecules.
\end{abstract}

\section{Introduction}

The higly reactive molecule formaldehyde $\left(\mathrm{H}_{2} \mathrm{CO}\right)$ is present at the level of a few percent in cometary and probably also in interstellar ices, making it one of the more abundant constituents after water (Mumma and Reuter 1989). This paper reports the results of experiments on analogues of astrophysical ice mixtures $\left(\mathrm{H}_{2} \mathrm{O}, \mathrm{H}_{2} \mathrm{CO}, \mathrm{NH}_{3}, \mathrm{CH}_{3} \mathrm{OH}\right)$ that were performed to investigate the possible role that formaldehyde may have in the formation of cometary and interstellar organic molecules.

\section{Experimental Results}

Ice mixtures containing water $\left(\mathrm{H}_{2} \mathrm{O}\right)$, ammonia $\left(\mathrm{NH}_{3}\right)$ and $\mathrm{H}_{2} \mathrm{CO}$ in various concentrations were prepared at $10 \mathrm{~K}$. Upon warm-up, reactions involving formaldehyde took place between $40-180 \mathrm{~K}$, producing organic residues in high yields. Remarkably, these residues seem to consist of only 3 products. The first product can be obtained from $\mathrm{H}_{2} \mathrm{CO}$ ice with traces of $\mathrm{NH}_{3}$. Its IR spectrum identifies it as polyoxymethylene (POM; [- $\left.\mathrm{CH}_{2}-\mathrm{O}-\mathrm{CH}_{2}-\mathrm{O}\right]_{n}$ ), a well known $\mathrm{H}_{2} \mathrm{CO}$ polymerization product. The second product, designated $\mathrm{X}$, is produced by reactions between $\mathrm{H}_{2} \mathrm{CO}$ and $\mathrm{NH}_{3}$. Its IR spectrum reveals $\mathrm{C}-\mathrm{H}, \mathrm{C}-\mathrm{O},-\mathrm{NH}_{2}$ and possibly $\mathrm{O}-\mathrm{H}$ groups. It evaporates below $230 \mathrm{~K}$, implying a small structure with $<\approx 2 \mathrm{C}$ atoms. The third product, designated $Y$, is obtained from reactions between $\mathrm{H}_{2} \mathrm{CO}$ and $\mathrm{H}_{2} \mathrm{O}$. It contains $\mathrm{O}-\mathrm{H}, \mathrm{C}-\mathrm{H}$, and $\mathrm{C}-\mathrm{O}$ groups and seems to have ether- as well as alcohol-type properties. Evaporating below $260 \mathrm{~K}$, it should contain at most $\sim 2 \mathrm{C}$ atoms.

Figure 1 shows the yields of POM, $X$, and $Y$, i.e., the fraction of the carbon initially deposited as formaldehyde that ends up in these products, as well as the total residue yield as a function of the initial $\left[\mathrm{NH}_{3} / \mathrm{H}_{2} \mathrm{CO}\right]$ ratio at $\left[\mathrm{H}_{2} \mathrm{CO} / \mathrm{H}_{2} \mathrm{O}\right]=0.05$. It can be seen that traces of ammonia $\left(\left[\mathrm{NH}_{3} / \mathrm{H}_{2} \mathrm{CO}\right]>\approx 0.005\right)$ are required to initialize reactions involving $\mathrm{H}_{2} \mathrm{CO}$ and the production of an organic residue. For $\left[\mathrm{NH}_{3} / \mathrm{H}_{2} \mathrm{CO}\right]>\approx 0.4$, the conversion of formaldehyde to organic molecules is almost $100 \%$. The produced relative 
amounts of POM, $X$ and $Y$ depend sensitively on the initial ice composition.

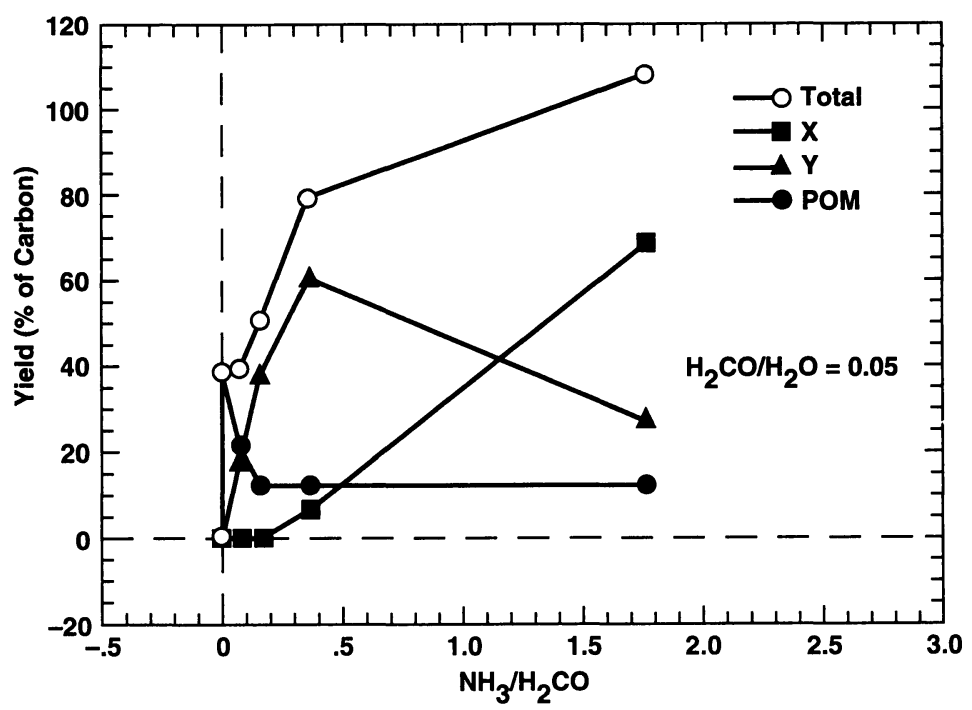

Figure 1. Yields of $P O M, X$ and $Y$ obtained upon warm-up of ices with initial ratio $\left[\mathrm{H}_{2} \mathrm{CO} / \mathrm{H}_{2} \mathrm{O}\right]=0.05$, as a function of $\mathrm{NH}_{3}$ concentration.

Introduction of $1-10 \%$ of methanol $\left(\mathrm{CH}_{3} \mathrm{OH}\right)$ in water-rich ices $\left(\left[\mathrm{H}_{2} \mathrm{CO} / \mathrm{H}_{2} \mathrm{O}\right] \approx\right.$ $0.05)$ with $\left[\mathrm{NH}_{3} / \mathrm{H}_{2} \mathrm{CO}\right]<\approx 0.01$ decreases the total yield of residue from $40 \%$ to 10 $20 \%$. Furthermore, the yield of POM drops to less than $3 \%$ and the residue is dominated by new alcohol-type compounds. For water-rich ices with $\left[\mathrm{NH}_{3} / \mathrm{H}_{2} \mathrm{CO}\right]>\approx$ 0.25 , adding $\mathrm{CH}_{3} \mathrm{OH}$ does not significantly change the organic residues.

\section{Astrophysical Implications}

Our experimental results have a number of astrophysical implications. Low temperature formaldehyde reactions in astrophysical ices are probably an important source of interstellar and cometary organic compounds and may account for $1-10 \%$ of the organic molecules detected in Comet Halley. Only a small number of compounds are produced $(4-6)$. For astrophysically relevant ices the major products are small $(<\approx 2$ $C$ atoms), highly O-rich $(\mathrm{O} / \mathrm{C} \approx 1)$ and have alcohol-, amine-, and ether-like properties, while POM is a minor product. The kind of molecules that are produced and their relative abundances trace the initial ice composition and concentrations.

\section{References}

Mumma, M. J., anci Reuter, D. C. (1989) 'On the Identification of Formaldehyde in Halley's Comet', ApJ 344, 940-948. 